\title{
ALIMENTARY FACTORS IN THE DEVELOPMENT OF GASTRIC INTESTINAL METAPLASIA IN FUNCTIONAL DYSPEPTIC PATIENTS
}

\author{
Aline Gamarra TABORDA and João Carlos PROLLA
}

\begin{abstract}
Context - Intestinal metaplasia of the stomach is a lesion in which metaplasia of gastric epithelial cells occurs for an intestinal phenotype. Gastric intestinal metaplasia is a lesion associated with an increase in the risk of gastric carcinoma development. Epidemiologic studies indicate a relation between dietary habits and stomach cancer development, some habits increasing the risk for it, and others have a protective effect, suggesting that antioxidants, such as vitamins A, C, and E, decrease the risk of this type of cancer. The relationship of these alimentary factors and intestinal metaplasia is unknown. Methods - It is a case-control, observational study in which 320 patients with functional dyspepsia, divided in two groups, were assessed. The case I group (individuals with intestinal metaplasia) had their dietary pattern compared to that of the control group, constituted of individuals similar to those in the case group but without intestinal metaplasia, through a food frequency questionnaire. Results - The analysis of the dietary pattern of functional dyspeptic patients with intestinal metaplasia, and its comparison with those without intestinal metaplasia, showed a higher frequency of canned and smoked foods consumption in the first group and, on the other hand, a higher consumption of fruits and vegetables in patients without intestinal metaplasia. No effect of salt consumption was detected. Conclusions - The results obtained in this study suggest changes in the diet, with a decrease in the consumption of smoked and canned foods, and an increase in the consumption of fruits and vegetables, can lead to a diminution of gastric intestinal metaplasia cases.
\end{abstract}

HEADINGS - Metaplasia. Intestines. Stomach. Dyspepsia. Food habits.

\section{INTRODUCTION}

The functional gastrointestinal illnesses are recognized public health problems. They are characterized by a series of conditions and chronic gastrointestinal symptoms that cannot be explained by structural alterations or possible identification by the currently clinical available tests ${ }^{(1,28)}$. The term dyspepsia is used to define recurrent or persistent symptoms of discomfort and/or pain in the upper abdomen ${ }^{(1,28)}$.

The etiological factors involved in the genesis of the gastric cancer are not entirely known. Epidemiological studies demonstrate the importance of ambiental factors, especially alimentary, in its pathogenesis. A factor that has been investigated in gastric oncogenesis is the infection by Helicobacter pylori leading to chronic gastritis, atrophy of the mucosa and intestinal metaplasia; having, thus, participation in the chain of events leading to gastric cancer ${ }^{(6,21,23)}$.
The alimentary factors of increased risk more are salty diets, smoked fish, high nitrate content (the nitrates are converted in carcinogenic nitrates by the intestinal bacteria) $)^{(12,17,29)}$.

Raw vegetable consumption, citric fruits and breads with high fiber are associated to a lesser risk of gastric cancer. The ascorbic acid and $\beta$-carotene, found in fruits and vegetables, act as antioxidants and the ascorbic acid also can prevent the nitrates conversion into nitrites ${ }^{(4,17)}$.

The atrophic chronic gastritis and the intestinal metaplasia (IM) are associated with this neoplasm. The pre-neoplastic states, such as atrophic chronic gastritis and intestinal metaplasia would evolve into dysplasia and this for the cancer in about $10 \%$ of the cases, after many years ${ }^{(14,18)}$.

The IM of the stomach is an injury that consists of the transdifferentiation of the gastric epithelial cells into an intestinal phenotype. The gastric IM is

Declared conflict of interest of all authors: none.

Post-graduation in Gastroenterology - Federal University of Rio Grande do Sul (UFRGS), Porto Alegre, RS, Brazil.

Correspondence: Dr. Aline Gamarra - Rua Carumbé, 120 - apt. 706 - 91420-040 - Porto Alegre, RS, Brazil. Email: alinegamarrat@hotmail.com 
considered a pre-neoplastic injury that is associated with an increased risk of gastric carcinoma ${ }^{(5,22)}$.

The process of intestinal differentiation that occurs in the gastric mucosa is dependent of the expression of the gene homeobox CDX2 - a factor of crucial transcription for the intestinal differentiation in such a way in its normal localization, the intestine, as in other tissues ${ }^{(19,26)}$.

Free radicals are produced by chemical modifications of proteins, lipids, carbohydrates and nucleotides, resulting in a variety of biological consequences, including injury, mutations, carcinogenesis, impaired immune system, diseases and cell death ${ }^{(8,11,21)}$.

The continuous production of free radicals during the metabolic processes led to the development of many mechanisms of antioxidant defense to limit the intracellular levels and to hinder the induction of damages ${ }^{(10,21,27)}$.

The antioxidant substances are a heterogeneous group consisting of vitamins, minerals, pigments and other vegetal composites; are also enzymes, acting these as blocking agents of the harmful effects of the free radicals ${ }^{24,25,30,31)}$.

There are also indications that a diet consisting of fresh vegetables and fruits is protective in numerous studies suggesting that antioxidants such as vitamins $\mathrm{A}, \mathrm{C}$ and $\mathrm{E}$, reduce the risk of gastric cancer ${ }^{(4,11)}$.

This study aimed to evaluate the potential relationship between these dietary factors and the development of gastric intestinal metaplasia in functional dyspeptic subjects.

\section{METHODS}

\section{Delineation}

A case-control, observational, longitudinal, analytical study, in which a group I cases (individuals with intestinal metaplasia) has its dietary patterns compared to the group of individuals similar to the case group, called the control (without intestinal metaplasia) through a questionnaire of food frequency.

\section{Population and sample}

Functional dyspeptic patients were evaluated at The HEROES (Helicobacter Eradication Relief of Dyspeptic Symptoms) trial was a randomized double-blind, placebo-controlled clinical trial. The study was conducted in a single academic hospital, the Hospital de Clínicas de Porto Alegre, Porto Alegre, RS, Brazil. The local institutional review board approved the trial protocol. Written informed consent was obtained from all patients prior to enrollment The research project $(05-422)$ and informed consent were approved, on 21/12/2005, by the Scientific and Research Committee and Ethics in Health Research Group and Graduate Hospital de Clínicas de Porto Alegre.

\section{Inclusion criteria}

Included patients with more than 18 years of age with the clinical criteria for functional dyspepsia according to Rome III Consensus, which includes pain or discomfort centered in the upper abdomen for a period equal to or greater than 3 months, or with normal endoscopies or only with endoscopic gastritis according to Sydney classification ${ }^{(15)}$.

Any diagnosis of metaplasia was confirmed histologically. Three biopsy specimens were obtained from the body of the stomach, three from the antrum, and two from the incisura angularis. One specimen from each anatomical region was used for the urease test, and the others were used for histologic examination by two pathologists.

\section{Description of methods for assessment of dietary patterns}

The evaluation of the alimentary pattern was performed using the Frequency Questionnaire Food Consumption, a qualitative instrument, which includes a list of foods, and we analyzed the frequency of daily intake, 3-4 times a week, 1-2 times a week, less than once a week, less than in a month or never.

\section{Statistical analysis}

The variables were divided into two groups where daily and 3-4 times per week were considered high intake, and 1-2 times a week, less than once a week, less than in a month or never were considered low intake.

Continuous variables were expressed as means and standard deviations and comparison groups were analyzed using the $t$ test for independent samples. Qualitative variables expressed as percentages and comparisons analyzed using Fisher's exact test. All tests two-tailed, and $P<0.05$ were considered statistically significant. Multivariate analysis with logistic regression was obtained.

\section{RESULTS}

We evaluated 320 patients with functional dyspepsia, 70 of these patients had intestinal metaplasia, which corresponds to $21 \%$ of the population studied.

In Table 1 we list the pattern of food consumption by patients with and without intestinal metaplasia.

Salt intake was subjected to qualitative assessment by having patients taking them offered three response options, which were: little, moderate or high salt intake; $55 \%$ of patients with intestinal metaplasia rated their salt consumption as moderate, the patients without intestinal metaplasia chose this same alternative in the proportion of $61 \%$, this difference was not significant according to Fisher's exact test. 
TABLE 1. Pattern of food consumption by patients with and without intestinal metaplasia

\begin{tabular}{|c|c|c|c|c|c|}
\hline & \multirow{2}{*}{ Frequency of consumption } & \multicolumn{2}{|c|}{ Group } & \multirow{2}{*}{$\mathrm{n}$} & \multirow[b]{2}{*}{ OR } \\
\hline & & Without metaplasia & With metaplasia & & \\
\hline \multirow[t]{2}{*}{ Food 1} & \multirow{3}{*}{$\begin{array}{l}\text { Low consumption } \\
\text { High consumption }\end{array}$} & 81 & 33 & 114 & \multirow{3}{*}{$\begin{array}{c}1,861 \\
(1,089-3,181)\end{array}$} \\
\hline & & 169 & 37 & 206 & \\
\hline Total & & 250 & 70 & 320 & \\
\hline \multirow[t]{2}{*}{ Food 2} & Low ingestion & 168 & 57 & 225 & \multirow{3}{*}{$\begin{array}{c}2,140 \\
(1,117-4,094)\end{array}$} \\
\hline & \multirow[t]{2}{*}{ High consumption } & 82 & 13 & 95 & \\
\hline Total & & 250 & 70 & 320 & \\
\hline Food 3 & Low ingestion & 101 & 42 & 143 & \multirow{3}{*}{$\begin{array}{c}2,213 \\
(1,293-3,788)\end{array}$} \\
\hline & \multirow[t]{2}{*}{ High consumption } & 149 & 28 & 177 & \\
\hline Total & & 250 & 70 & 320 & \\
\hline Food 4 & Low ingestion & 181 & 55 & 236 & \multirow{3}{*}{$\begin{array}{c}1,398 \\
(0,746-2,617)\end{array}$} \\
\hline & \multirow[t]{2}{*}{ High consumption } & 69 & 15 & 84 & \\
\hline Total & & 250 & 70 & 320 & \\
\hline Food 5 & Low ingestion & 234 & 24 & 258 & \multirow{3}{*}{$\begin{array}{c}28,031 \\
(13,884-56,588)\end{array}$} \\
\hline & \multirow[t]{2}{*}{ High consumption } & 16 & 46 & 62 & \\
\hline Total & & 250 & 70 & 320 & \\
\hline Food 61 & Low ingestion & 193 & 47 & 240 & \multirow{3}{*}{$\begin{array}{c}0,604 \\
(0,339-1,073)\end{array}$} \\
\hline & \multirow{2}{*}{ High consumption } & 57 & 23 & 80 & \\
\hline Total & & 250 & 70 & 320 & \\
\hline Food 7 & Low ingestion & 236 & 57 & 293 & \multirow{3}{*}{$\begin{array}{c}0,260 \\
(0,118-0,575)\end{array}$} \\
\hline & \multirow[t]{2}{*}{ High consumption } & 14 & 13 & 27 & \\
\hline Total & & 250 & 70 & 320 & \\
\hline Food 8 & Low ingestion & 127 & 18 & 145 & \multirow{3}{*}{$\begin{array}{c}3,032 \\
(1,687-5,444)\end{array}$} \\
\hline & \multirow[t]{2}{*}{ High consumption } & 121 & 52 & 173 & \\
\hline Total & & 250 & 70 & 320 & \\
\hline \multirow{2}{*}{\multicolumn{2}{|c|}{$\begin{array}{l}\text { Food 1: fruits in general; } \\
\text { Food 2: citric fruits; } \\
\text { OR: odds ratio }\end{array}$}} & getables; & Food 5: smoked foods; & Food 7:canned foods; & \\
\hline & & regetables; & Food 6:embedded foods ; & Food 8: cheeses; & \\
\hline
\end{tabular}

It was noted that the consumption of alcohol and tobacco were also surveyed showing no statistical differences between the groups surveyed.

\section{DISCUSSION}

Intestinal metaplasia, has been studied mainly in a descriptive ways. Although said to be a precancerous condition, a functional link between intestinal metaplasia and carcinogenesis remains speculative. However, intestinal metaplasia has been considered a risk factor for the development of intestinal-type gastric adenocarcinoma. It is known that genetic, environmental and food are involved. However, a precancerous lesion takes about 20 years to develop into the severe form. Thus, the most effective measure to reduce the risk factors in relation to food is a balanced diet starting early, in childhood ${ }^{(19,22)}$.
As shown in Table 1 (food 1 and 2) can be observed that a high frequency of consumption of fruits in general and citrus fruit, these foods have a protective effect on relation to the development of intestinal metaplasia, as evidenced by the $\mathrm{OR}=1.861 \mathrm{CI}=1.089$ to 3.181 .

Studies have shown that diets rich in vegetables and fruits is associated with low incidence of chronic degenerative diseases, such as some types of cancer (lung, breast, prostate) and cardiovascular diseases, photoprotective effects, as well as the effects of feminine hormone replacement therapy ${ }^{(4,11,20)}$.

It is widely known that the consumption of vegetables helps to reduce the risk of gastric cancer. However, the incidence rates of gastric cancer remain high in some populations, such as Japan and Korea, despite a high intake of total vegetables. This may be due to the fact that Japanese and Koreans consume vegetables mainly processed as salted 
or pickled vegetables instead of fresh vegetables ${ }^{(2,9)}$. In our study we evaluated the frequency of intake of green and yellow vegetables, and it was observed that the high frequency of consumption of green vegetables denoted an inverse correlation to the development of intestinal metaplasia, as evidenced in Table 1 (food 3), however in yellow vegetables (food 4) there were no significant differences between the groups.

In a population-based study conducted by Kim et al.(9) they analyzed the consumption of fresh vegetables and of pickled vegetables, relating them to the risk of gastric can$\operatorname{cer}^{(9)}$. It was observed that a high intake of fresh vegetables was significantly associated with a decreased risk of gastric cancer, but that a high intake of pickled vegetables was significantly associated with an increased risk. The results of this 2010 study show that a high intake of pickled vegetables may increase the risk for gastric cancer and suggest that a high intake of fresh vegetables is important for reducing the risk of gastric cancer. In our study, we found the frequency of consumption of individuals, although there were no significant differences between groups in relation to consumption of canned food in general (Table 1 food 7) and the development of intestinal metaplasia.

The most consistent inverse association which can be detected in epidemiological studies, refers to a higher consumption of fruits and vegetables, especially dark green color and yellow-orange, or high serum $\beta$-carotene, and low rates of cancer ${ }^{(3,7,13)}$

In the present study, we found a significantly higher risk of developing intestinal metaplasia in patients whose food intake frequency of smoking foods was high, v.g., daily, or about 3-4 times a week, as seen in Table 1 (food 5).

Among the foods identified as those that increase the risk are primarily the smoked foods, cured meats and other foods preserved in salt.

Foods with high nitrate content, foods cured, tinned, with dyes or conserved in salt are factors of risk for this type of cancer. Other factors as the conservation of foods and the water ingestion from wells that also contain high nitrate concentration are related with the incidence of stomach cancer $^{(16,30)}$.

More recently begun to be recognized the potential carcinogenic effects of nitrosamines and nitrosamides, generically called N-compounds, substances formed in the interaction between a group of secondary nitrogen (which can be an amine or amide, a urea or an alkyl-ring peptide) and a nitrite. The evidence that the populations most at risk for gastric cancer have diets rich in substrates for the process of endogenous $\mathrm{N}$-compounds triggered the interest in the evaluation of these substances in the genesis of gastric cancer ${ }^{(6)}$.

The N-nitroso compounds, the main source for most people, the endogenous formation, a process that can be inhibited by polyphenols. A case-control study in Mexico City in 2004-2005, including 257 cases with gastric cancer (histologically confirmed) and 478 controls was conducted to estimate the risk of gastric cancer in relation to individual and combined consumption of polyphenols and precursors $\mathrm{N}$-compounds ${ }^{(6)}$. The intake of polyphenols, nitrate and nitrite were estimated by a food frequency questionnaire. High intake of secoisolariciresinol and coumestrol cinnamic acids were associated with a reduction of about $50 \%$ in the risk of gastric cancer. A high intake of total nitrite and nitrate and nitrite animal doubled the risk of gastric cancer.

The odds ratio of about 2 times was observed among individuals with low consumption of cinnamic acids, secoisolariciresinol and coumestrol and high intake of nitrate or nitrite animal, compared with a high intake of polyphenols and nitrate low consumption of animals or nitrite, respectively( ${ }^{(6)}$.

By analysis of Table 1 (food 6 and 7), regarding the frequency of consumption of embedded foods and canned foods, there was no statistical significance between the groups with and without metaplasia.

In this study, a relationship between salt intake and intestinal metaplasia was not observed, since, in both groups, most patients rated their daily salt consumption as moderate, with this, there were no significant differences between them.

Work done by Dias-Neto et al. ${ }^{(2)}$, sought the association between salt intake and precancerous lesions and how they can help to clarify the causal relationship to gastric cancer. They systematically reviewed 17 articles addressing the association between dietary salt exposure and gastric intestinal metaplasia and performed a meta-analysis. Exposure to salt was estimated by evaluating the consumption of salty foods, preference for salty foods, salt use and urinary excretion of sodium. The odds ratio of 1.68 with $(\mathrm{CI})=0.98$ to 2.90 , I $(2)=55.4 \%$ for the association between salted salty/and intestinal metaplasia (four studies) and $\mathrm{OR}$ was $1.53(95 \% \mathrm{CI}=0.72$ to 3.24 , I $(2)=76.8 \%)$, preferably salt. There was a positive association but not statistically significant between intestinal metaplasia and urinary sodium excretion.

The preference for salty meals may increase the risk of developing stomach cancer. Evaluating more than 2.2 million Koreans ages 30 to 80 , researchers found that a diet high in salt can increase by $10 \%$ the chances of developing the disease. In the study, 9,620 men and 2,773 women who had the disease prefer a saltier $\operatorname{diet}^{(9)}$.

\section{CONCLUSIONS}

We found that foods such as canned and smoked have higher consumption in patients with intestinal metaplasia, 
indirectly supporting the hypothesis that they can act as potential carcinogens.

Patients without intestinal metaplasia have a significantly higher consumption of fruits and vegetables in general.

Cheese consumption, showed a greater tendency to consumption in patients with metaplasia, in contrast patients without metaplasia had a larger trend in the consumption of legumes.

In relation to the consumption of salt our results do not corroborate a role in the process of gastric intestinal metaplasia.

We conclude that dietary modification by reducing the intake of foods such as smoked and canned, as well as the increased intake of fruits, may represent a practical strategy to prevent gastric cancer by decreasing case of intestinal metaplasia.

Further investigation of these associations in prospective cohort studies are needed.

Taborda AG, Prolla JC. Fatores alimentares envolvidos no desenvolvimento de metaplasia intestinal em dispépticos funcionais. Arq Gastroenterol. 2012;49(3):208-13.

RESUMO - Contexto - A metaplasia intestinal do estômago é uma lesão onde ocorre a metaplasia das células epiteliais gástricas para um fenótipo intestinal. A metaplasia intestinal gástrica é considerada uma lesão associada ao aumento do risco de desenvolvimento de carcinoma gástrico. Estudos epidemiológicos indicam uma relação entre hábitos alimentares e o risco de desenvolvimento de câncer de estômago: tanto podendo ter efeito carcinogênico gástrico, como fator protetor, sugerindo que os antioxidantes como as vitaminas A, C e E diminuem o risco desse tipo de câncer. Não se conhece a influência desses fatores alimentares na metaplasia intestinal gástrica. Material - Trata-se de estudo caso-controle, observacional, para o qual foram avaliados 320 pacientes com dispepsia funcional, separados em dois grupos, um grupo de casos I (indivíduos com metaplasia intestinal) teve seus hábitos alimentares comparados aos do grupo de casos-controle (sem metaplasia intestinal), através de um questionário de frequência de consumo alimentar. Resultados - Ao analisarmos o padrão alimentar dos pacientes dispépticos funcionais com metaplasia intestinal e compará-lo com o padrão daqueles que não possuem metaplasia intestinal, constatou-se que os pacientes com metaplasia intestinal consomem mais alimentos como os enlatados e defumados, enquanto os pacientes sem metaplasia intestinal apresentam consumo expressivamente maior de frutas em geral e vegetais. Diferença no padrão de consumo de sal não foi identificada. Conclusões - Através dos resultados obtidos no presente estudo podemos supor que a modificação da dieta, por meio da diminuição na ingestão de alimentos como defumados e enlatados e acréscimo na ingestão de frutas e vegetais pode levar a diminuição de casos de metaplasia intestinal.

DESCRITORES - Metaplasia. Intestinos. Estômago. Dispepsia. Hábitos alimentares. 


\section{REFERENCES}

1. Corazziari E. Definition and epidemiology of functional gastrointestinal disorders. Best Pract Res Clin Gastroenterol. 2004;18:613-31.

2. Dias-Neto M, Pintalhao M, Ferreira M, Lunet N. Salt intake and risk of gastric intestinal metaplasia: systematic review and meta-analysis. Nutr Cancer. 2010;62:133-47.

3. Duriancik DM, Lackey DE, Hoag KA. Vitamin A as a regulator of antigen presenting cells. J Nutr. 2010;140:1395-9.

4. Epplein M, Shu XO, Xiang YB, Chow WH, Yang G, Li HL, Ji BT, Cai H, Gao YT, Zheng W. Fruit and vegetable consumption and risk of distal gastric cancer in the Shanghai women's and men's health studies. Am J Epidemiol. 2010;172:397406.

5. Genta RM, Rugge M. Review article: pre-neoplastic states of the gastric mucosa - a practical approach for the perplexed clinician. Aliment Pharmacol Ther. 2001;15(Suppl 1):43-50.

6. Hernández-Ramírez RU, Galván-Portillo MV, Ward MH, Agudo A, González CA, Oñate-Ocaña LF, Herrera-Goepfert R, Palma-Coca O, López-Carrillo L. Dietary intake of polyphenols, nitrate and nitrite and gastric cancer risk in Mexico City. Int J Cancer. 2009;125:1424-30.

7. Jenab M, Riboli E, Ferrari P, Friesen M, Sabate J, Norat T, Slimani N, Tjønneland A, Olsen A, Overvad K, Boutron-Ruault MC, Clavel-Chapelon F, Boeing H, Schulz M, Linseisen J, Nagel G, Trichopoulou A, Naska A, Oikonomou E, Berrino F, Panico S, Palli D, Sacerdote C, Tumino R, Peeters PH, Numans ME, Bueno-de-Mesquita HB, Büchner FL, Lund E, Pera G, Chirlaque MD, Sánchez MJ, Arriola L, Barricarte A, Quirós JR, Johansson I, Johansson A, Berglund G, Bingham S, Khaw KT, Allen N, Key T, Carneiro F, Save V, Del Giudice G, Plebani M, Kaaks R, Gonzalez CA. Plasma and dietary carotenoid, retinol and tocopherol levels and the risk of gastric adenocarcinomas in the European prospective investigation into cancer and nutrition. Br J Cancer. 2006;95:406-15.

8. Kim HJ, Kim MK, Chang WK, Choi HS, Choi BY, Lee SS. Effect of nutrient intake and Helicobacter pylori infection on gastric cancer in Korea: a case-control study. Nutr Cancer. 2005;52:138-46.

9. Kim J, Park S, Nam BH. Gastric cancer and salt preference: a population-based cohort study in Korea. Am J Clin Nutr. 2010;91:1289-93.

10. Konturek PC, Kania J, Gessner U, Konturek SJ, Hahn EG, Konturek JW. Effect of vitamin C-releasing acetylsalicylic acid on gastric mucosal damage before and after Helicobacter pylori eradication therapy. Eur J Pharmacol. 2004;506:169-77.

11. Larsson S C, Bergkvist L, Näslund I, Rutegård J, Wolk A. Vitamin A, retinol, and carotenoids and the risk of gastric cancer: a prospective cohort study. Am J Clin Nutr. 2007;85:497-503.

12. Lazarevic K, Nagorni A, Rancic N, Milutinovic S, Stosic L, Ilijev I. Dietary factors and gastric cancer risk: hospital-based case control study. J Buon. 2010;15:89-93.

13. Lissowska J, Gail MH, Pee D, Groves FD, Sobin LH, Nasierowska-Guttmejer A Sygnowska E, Zatonski W, Blot WJ, Chow WH. Diet and stomach cancer risk in Warsaw, Poland. Nutr Cancer 2004;48:149-59.
14. Matysiak-Budnik T, Mégraud F. Helicobacter pylori infection and gastric cancer. Eur J Cancer. 2006;42:708-16.

15. McColl K, Murray L, El-Omar E; Dickson A, El-Nujumi A, Wirz A, Kelman A, Penny C, Knill-Jones R, Hilditch T. Symptomatic benefit from eradicating Helicobacter pylori infection in patients with nonulcer dyspepsia. N Engl J Med. 1998;339:1869-74.

16. Mirvish SS. Experimental evidence for inhibition of N-nitroso compound formation as a factor in the negative correlation between vitamin $\mathrm{C}$ consumption and the incidence of certain cancers. Cancer Res. 1994;54:1948s-51s.

17. Nouraie M, Pietinen P, Kamangar F, Dawsey SM, Abnet CC, Albanes D, Virtamo J, Taylor PR. Fruits, vegetables, and antioxidants and risk of gastric cancer among male smokers. Cancer Epidemiol Biomark Prev. 2005;14:2087-92.

18. Peek RM, Blasern MJ. Helicobacter pylori and gastrointestinal tract adenocarcinomas. Nat Rev Cancer. 2002;2:28-37.

19. Pitot HC. The molecular biology of carcinogenesis. Cancer. 1993;72(suppl 3):962 70.

20. Pool-Zobel BL, Bub A, Müller H, Wollowski I, Rechkemmer G. Consumption of vegetables reduces genetic damage in humans: first results of a human intervention trial with carotenoid-rich foods. Carcinogenesis. 1997;18:1847-50.

21. Poulsen HE, Prieme H, Loft S. Role of oxidative DNA damage in cancer initiation and promotion. Eur J Cancer Prev. 1998;7:9-16.

22. Saikawa Y, Fukuda K, Takahashi T, Nakamura R, Takeuchi H, Kitagawa Y. Gastric carcinogenesis and the cancer stem cell hypothesis. Gastric Cancer. 2010;13:11-24.

23. Shah MA, Ajani JA. Gastric cancer an enigmatic and heterogeneous disease. JAMA. 2010;303:1753-4.

24. Sies H. Strategies of antioxidant defence. Eur J Biochem. 1993;215:213-9.

25. Sies H, ed. Antioxidants in disease, mechanisms and therapy. Academic Press; 1996. p.119-49.

26. Silberg DG, Sullivan J, Kang E, Swain GP, Moffett J, Sund NJ, Sackett SD, Kaestner KH. Cdx2 ectopic expression induces gastric intestinal metaplasia in transgenic mice. Gastroenterology. 2002;122:689-96.

27. Talley NJ, Stanghellini V, Heading RC, Koch KL, Malagelada JR, Tytgat GN. Functional gastroduodenal disorders. Gut. 1999;45:II37-42.

28. Tirzitis G, Bartosz G. Determination of antiradical and antioxidant activity: basic principles and new insights. Acta Biochim Pol. 2010;57:139-42.

29. Uemura N, Okamoto S, Yamamoto S, Matsumura N, Yamaguchi S, Yamakido M, Taniyama K, Sasaki N, Schlemper RJ. Helicobacter pylori infection and the development of gastric cancer. N Engl J Med. 2001;345:784-9.

30. Valko M, Rhodes CJ, Moncol J, Izakovic M, Mazur M. Free radicals, metals and antioxidants in oxidative stress-induced cancer. Chem Biol Interact. 2006;160:1-40.

31. Wang G. Alamuri P. Maier RJ. The diverse antioxidant systems of Helicobacter pylori. Mol Microbiol. 2006;61:847-60. 